\title{
Epidemiology of Hantavirus Infection in Thousand Islands Regency of Jakarta, Indonesia
}

\author{
Ima-Nurisa IBRAHIM ${ }^{1)}$, Kenta SHIMIZU²), Kumiko YOSHIMATSU²), Andre YUNIANTO ${ }^{1)}$, Ervi SALWATI ${ }^{1)}$, \\ Shumpei P. YASUDA ${ }^{2)}$, Takaaki KOMA ${ }^{2)}$, Rika ENDO ${ }^{2)}$ and Jiro ARIKAWA ${ }^{2) *}$ \\ 1) National Institute of Health Research and Development, Ministry of Health, Jl. Percetakan Negra 29, Jakarta 10560, Indonesia \\ ${ }^{2)}$ Department of Microbiology, Hokkaido University Graduate School of Medicine, Kita-15, Nishi-7, Kita-ku, Sapporo 060-8638, Japan
}

(Received 3 October 2012/Accepted 27 February 2013/Published online in J-STAGE 18 March 2013)

ABSTRACT. Hemorrhagic fever with renal syndrome (HFRS) is a rodent-borne zoonotic disease caused by hantavirus infection. Many HFRS cases have been reported in East Asia and North Europe, while the situation in Southeast Asia remains unclear. In this study, the prevalence of hantavirus infection in rodents and humans in Thousand Islands regency, which is close to the port of Jakarta, one of the largest historic ports in Indonesia, was investigated. A total of 170 rodents were captured in 2005, and 27 (15.9\%) of the rodents were antibody-positive against Hantaan virus antigen in an immunofluorescence assay (IFA) and Western blotting. Despite the high prevalence in rodents, human sera collected from 31 patients with fever of unknown origin and 20 healthy volunteers in the islands in 2009 did not show positive reaction to the antigen in IFA. To identify the virus in rodents genetically, a total of 59 rodents were captured in 2009. Sera from the rodents were screened for antibody by ELISA, and lung tissues were subjected to RT-PCR. 20 (33.9\%) of the 59 rodents were antibody-positive, and 3 of those 20 rodents were positive for $\mathrm{S}$ and $\mathrm{M}$ genome segments of hantaviruses. Genetic analysis showed that the viruses belonged to Seoul virus and formed a cluster with those in Vietnam and Singapore. These results suggest that a unique group of Seoul viruses has spread widely in Southeast Asia.

KEY WORDS: epidemiology, hantavirus, Indonesia, rodent, Seoul virus.

doi: 10.1292/jvms.12-0442; J. Vet. Med. Sci. 75(8): 1003-1008, 2013

Hemorrhagic fever with renal syndrome (HFRS) is a rodent-borne zoonotic disease caused by hantavirus infection. Humans become infected through inhalation of excreta from infected rodents. The patients develop fever, renal disorder and hemorrhagic manifestation, resulting in death in $1-10 \%$ of cases. There are no effective therapeutic measures [19].

Hantaviruses belong to the genus Hantavirus, family Bunyaviridae. The genome is composed of three segments of single-stranded negative-sense RNA, designated as small (S), medium (M) and large (L) segments, encoding nucleocapsid protein $(\mathrm{N})$, glycoprotein (GP) and RNA-dependent RNA polymerase, respectively [20].

Many HFRS cases have been reported in East Asia and North Europe [11]. On the other hand, epidemiological information about hantaviruses in Southeast Asia is limited. There have been a few reports on hantavirus infection in humans and animals in Indonesia. Seoul virus (SEOV) in Rattus norvegicus in Jakarta was demonstrated serologically [8] and genetically [17]. Thottapalayam virus (TPMV) in shrews (Suncus murinus) in Thousand Islands regency was shown by serological examination [13]. A novel hantavirus designated as a Serang virus (SERV) was detected from $R$. tanezumi in Serang district of Banten Province by genetic examination [15]. These findings suggest that a variety of

*Correspondence to: Arikawa, J., Department of Microbiology, Hokkaido University Graduate School of Medicine, Kita-15, Nishi-7, Kita-ku, Sapporo 060-8638, Japan.

e-mail: j_arika@med.hokudai.ac.jp

(C)2013 The Japanese Society of Veterinary Science hantaviruses exist in Indonesia and may cause human diseases $[6,10]$. However, the prevalence of those viruses and the actual risk to human health remain unclear.

Thousand Islands regency of Jakarta consists of a string of 105 tiny islands in Java Sea and is located close to the port of Jakarta, which is largest historic port in Indonesia. Onrust Island, belonging to the Thousand Islands regency, is used to be an international and domestic quarantine seaport more than 50 years ago when Indonesia was still a Dutch colony. For a period of almost three hundred years, many ships visited the island from all over the world before going to other islands in the Indonesian archipelago. Considering the location and history of Thousand Islands regency, it is possible that unique hantaviruses exist there.

In this study, in order to determine the current status of hantavirus infection in Thousand Islands regency, rodent and human sera were collected and examined for the presence of antibodies against hantaviruses. Genetic analysis of the virus was also conducted.

\section{MATERIALS AND METHODS}

Sample collection: A total of 229 rodents (112 Rattus norvegicus and $117 R$. tanezumi) were captured in seven islands in Thousand Islands regency of Jakarta, Indonesia in 2005 and 2009 (Fig. 1, Tables 2 and 3). One hundred and seventy rodents were captured in Tidung, Panggang, Untung Jawa, Pari, Kotok and Rambut Islands in July and October 2005, and 59 rodents were captured in Tidung, Panggang and Karya Islands in June 2009. Tomahawk traps with roasted coconuts were set up in and outside the houses on each island. Species 
A

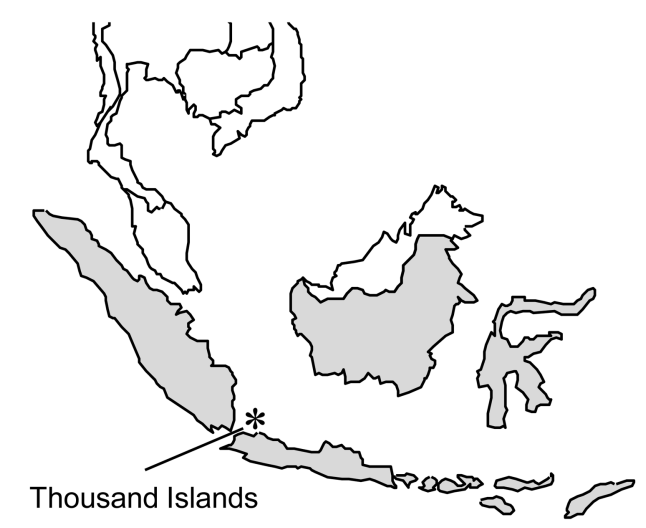

B

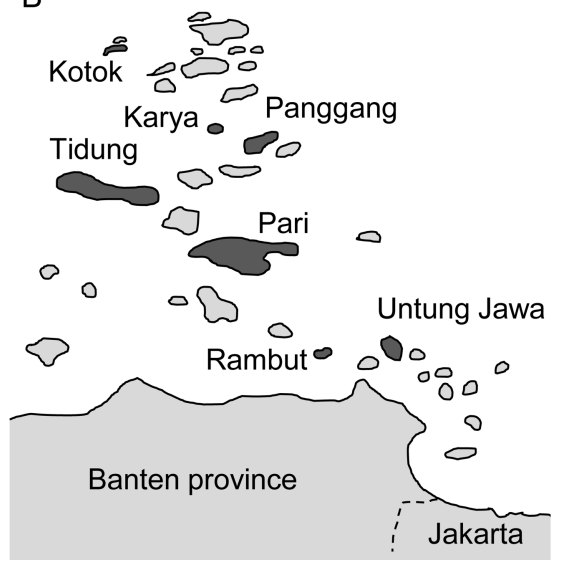

Fig. 1. The location of Thousand Islands regency of Jakarta, Indonesia (A) and islands where the survey was conducted (B).

Table 1. Primers used in this study

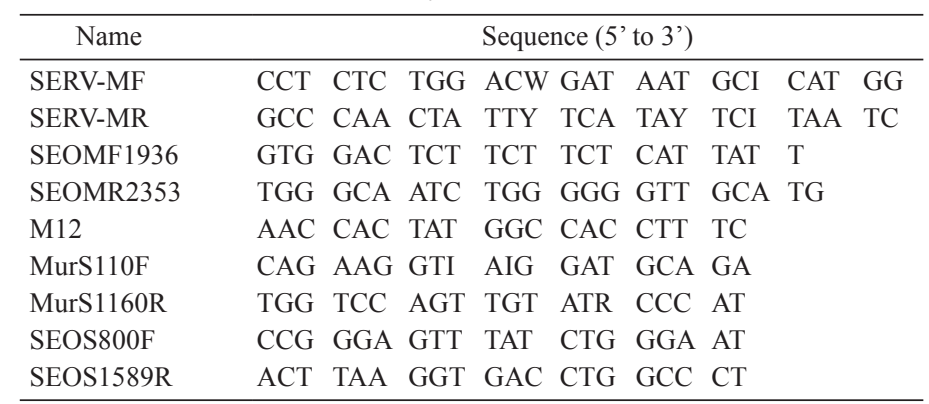

Table 2. Prevalence of hantavirus infection in rodents in 2005 determined by IFA and WB

\begin{tabular}{lcccc}
\hline \multirow{2}{*}{ Islands } & \multicolumn{4}{c}{ Species } \\
\cline { 2 - 5 } \multicolumn{2}{c}{$R$. norvegicus } & \multicolumn{2}{c}{$R$. tanezumi } \\
\hline Tidung & $5 / 29^{\mathrm{a})}$ & $(17.2)^{\mathrm{b})}$ & $0 / 26$ & $(0)$ \\
Panggang & $13 / 32$ & $(40.6)$ & $1 / 15$ & $(6.7)$ \\
Untung Jawa & $3 / 13$ & $(23.1)$ & $5 / 24$ & $(20.8)$ \\
Pari & $-\mathrm{c})$ & - & $0 / 23$ & $(0)$ \\
Kotok & - & - & $0 / 7$ & $(0)$ \\
Rambut & - & - & $0 / 1$ & $(0)$ \\
\hline Total & $21 / 74$ & $(28.4)$ & $6 / 96$ & $(6.3)$ \\
\hline
\end{tabular}

a) Number of antibody-positive sample/ Number of tested sample.

b) Positive rate (\%). c) No Sample.

were identified by outer appearance and sizes of body parts. Sera were collected from all of the rodents, while lung tissues were collected from rodents captured in 2009. A total of 51 human sera were collected from 31 patients with fever of unknown origin and from 20 healthy volunteers at community health centers in Tidung and Panggang Islands from June 2009 to October 2009 (Table 4).

Immunofluorescence assay (IFA): Rodent sera collected in 2005 and human sera were screened for antibodies against
Table 3. Prevalence of hantavirus infection in rodents in 2009 determined by ELISA

\begin{tabular}{lcllc}
\hline \multirow{2}{*}{ Islands } & \multicolumn{3}{c}{ Species } \\
\cline { 2 - 5 } \multicolumn{1}{c}{$R$.norvegicus } & \multicolumn{2}{c}{$R$. tanezumi } \\
\hline Tidung & $10 / 22^{\mathrm{a})}$ & $(45.5)^{\mathrm{b})}$ & $2 / 10$ & $(20.0)$ \\
Panggang & $6 / 13$ & $(46.2)$ & $1 / 9$ & $(11.1)$ \\
Karya & $1 / 3$ & $(33.3)$ & $0 / 2$ & $(0)$ \\
\hline Total & $17 / 38$ & $(44.7)$ & $3 / 21$ & $(14.3)$ \\
\hline
\end{tabular}

a) Number of antibody-positive sample/ Number of tested sample. b) Positive rate (\%).

hantaviruses by IFA as reported previously [23]. Hantaan virus (HTNV)-infected Vero E6 cells were used for the antigen. Sera were examined at 1:200 dilutions. Fluorescein isothiocyanate (FITC)-conjugated goat anti-rat IgG (KPL) and Protein A-FITC conjugate (EY-lab) were used for rodent and human sera, respectively. The specific granular pattern of fluorescence in cytoplasm was examined under a fluorescence microscope.

Western blotting $(W B)$ : After screening by IFA, the presence of antibodies against hantaviruses was confirmed by WB as reported previously [24]. Recombinant HTNV N expressed by a baculovirus system was used for the antigen. 
Table 4. Prevalence of hantavirus infection in human in 2009 determined by IFA

\begin{tabular}{lccc}
\hline \multicolumn{1}{c}{ Island } & Sick & Healthy & Total \\
\hline Tidung & $-^{\text {a) }}$ & $0 / 10$ & $0 / 10$ \\
Panggang & $0 / 31$ & $0 / 10$ & $0 / 41$ \\
\hline Total & $0 / 31$ & $0 / 20$ & $0 / 51$ \\
\hline
\end{tabular}

a) No sample.

Horseradish peroxidase (HRP)-conjugated goat anti-rat IgG (KPL) and 4-chloro-1-naphthol (Wako) were used for the secondary antibody and substrate, respectively.

Enzyme-linked immunosorbent assay (ELISA): Rodent sera collected in 2009 were screened for antibodies against hantaviruses by ELISA as reported previously [14]. Briefly, 96-well EIA/RIA plates (Corning) were coated with bacterially-expressed HTNV $\mathrm{N}$ at $4^{\circ} \mathrm{C}$ overnight. After blocking with PBS(-) containing 3\% bovine serum albumin (SigmaAldrich, St. Louis, MO, U.S.A.), the plates were incubated with 1:200 dilutions of heat-inactivated sera at room temperature for $1 \mathrm{hr}$. After washing with PBS(-) containing $0.05 \%$ Tween 20 three times, the plates were incubated with HRPconjugated goat anti-rat $\operatorname{IgG}(\mathrm{KPL})$ at room temperature for $1 \mathrm{hr}$. After washing and coloring with $o$-phenylenediamine (Sigma), optical density (OD) at a wavelength of $450 \mathrm{~nm}$ was measured by a spectrometer. Cutoff value was set at $\mathrm{OD}=0.864$, which was the minimum $\mathrm{OD}$ value in ELISA among the antibody-positive sera collected in 2005.

Sequence analysis of hantavirus genome: Total RNA isolated from rat lung tissue was used to examine hantavirusspecific cDNA as described previously [22]. Briefly, total RNAs were extracted from lung homogenate of antibodypositive rodents with ISOGEN (Nippon Gene, Tokyo, Japan) and reverse-transcribed into cDNAs by using random hexamer and SuperScript II reverse transcriptase (Life Technologies Japan Ltd., Tokyo, Japan) according to the manufacturer's instructions. cDNAs were amplified by polymerase chain reaction (PCR) by using AmpliTaq Gold (Life Technologies Japan Ltd.) and primers specific for hantaviruses (Table 1). PCR products were purified with a MinElute PCR purification kit (QIAGEN GmbH, Hilden, Germany) and subjected to nucleotide sequencing with a BigDye Terminator v3.1 Cycle Sequencing Kit and ABI PRISM 3130x1 Genetic Analyzer (ABI) according to the manufacturer's instructions. Phylogenetic analysis was performed by using GENETYX-MAC (ver. 15.0.1), CLUSTAL W (ver.1.83) and Njprot (ver. 2.3).

\section{RESULTS}

Prevalence of hantavirus infection in rodents captured in 2005: A total of 170 rodents ( $74 R$. norvegicus and $96 R$. tanezumi) were captured in six islands in Thousand Islands regency, and $27(15.9 \%)$ of the rodents were positive for antibodies against hantaviruses in IFA and WB (Table 2). Seroprevalences in R. norvegicus ranged from 17.2 to $40.6 \%$ (28.4\% in total), while those in $R$. tanezumi ranged from 0 to $20.8 \%$ (6.3\% in total). Antibodies were not detected from rodents in Pari, Kotok and Rambut Islands.

Screening of antibodies in rodents captured in 2009: Genetic identification of the virus in the rodents captured in 2005 was hampered by lack of samples feasible for genetic examination. Hence, rodents were captured again in 2009, and sera as well as lung tissues were collected for subsequent genetic examination. A total of 59 rodents ( 38 R. norvegicus and $21 R$. tanezumi) were captured in three islands, and 20 $(33.9 \%)$ of the rodents were antibody-positive in ELISA (Table 3). Similar to the results for rodents captured in 2005, seroprevalences in $R$. norvegicus were higher than those in R. tanezumi (33.3-46.2\% vs. 0-20.0\%). Seroprevalences in rodents in Tidung and Panggang Islands were continuously high in both 2005 and 2009.

Detection and sequence analysis of hantavirus genome: 20 lung tissues of the antibody-positive rodents captured in 2009 were examined for the presence of hantavirus genome by RT-PCR. We chose three specimens, such as KS74, KS80 and KS90, for the sequencing analysis, because they showed clear amplification patterns. cDNA fragments derived from $\mathrm{S}$ and $\mathrm{M}$ genome segments were amplified from three lung tissues of rodents: one $R$. norvegicus rodent captured in Panggang Island (KS90) and two R. norvegicus rodents captured in Tidung Island (KS74 and KS80). Partial sequences of the $\mathrm{S}$ segment (129 to 1,570 nucleotides) and the M segment (1,971 to 3,124 nucleotides) were determined. As for the $\mathrm{S}$ segment of KS90, the sequence of a shorter region (839 to 1,570 nucleotides) was determined. Alignment and phylogenetic analysis with known sequences showed that the viruses belonged to SEOV and formed a cluster with those detected in Vietnam and Singapore (Fig. 2) [9, 12, 21].

Prevalence of hantavirus infection in residents of the islands: To estimate the risk of hantavirus infection in residents, 31 sera of patients with fever of unknown origin and 20 sera of healthy volunteers in Tidung and Panggang Islands were screened for antibodies against hantaviruses by IFA (Table 4). Despite the relatively high prevalence in rodents, there were no antibody-positive sera in either patients or healthy volunteers.

\section{DISCUSSION}

Hantavirus-infected rodents have been reported in Southeast Asian countries including Vietnam, Cambodia, Thailand and Singapore [2, 9, 12, 18, 21]. Antibody positivity among humans has also been reported in Asian countries including India, Sri Lanka and Vietnam $[3,5,7]$. In the present study, we found SEOV-positive rodents in Thousand Islands regency of Jakarta in Java Sea, where many ships traffic frequently. In addition, phylogenetic analysis showed that Indonesian SEOV belongs to the same lineage as that of SEOV in Vietnamese and Singapore. These results suggest that SEOV was transported through movement of people accompanied by infected rodents beyond the Java Sea and that a unique group of SEOV spread widely in Southeast Asia.

Generally, hantaviruses are thought to have co-evolved with host rodents [16]. Indonesia is thought to be the area 
A

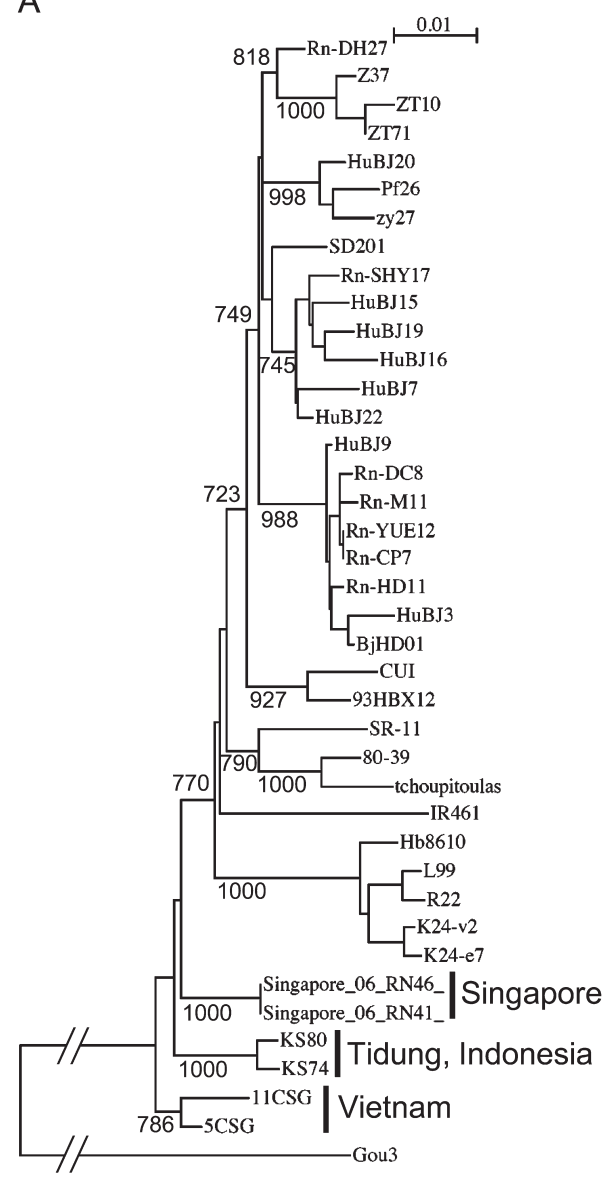

B

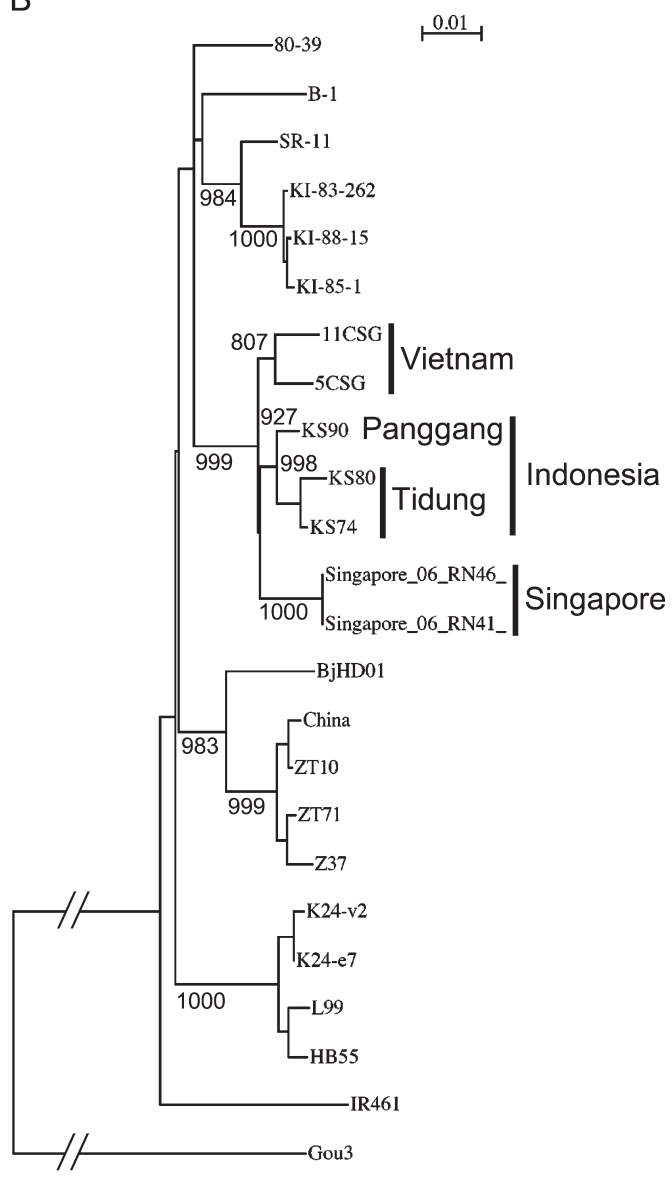

Fig. 2. Phylogenetic trees generated by the neighbor-joining method based on 129 to 1,570 nucleotides of the $\mathrm{S}$ segment (A) and 1,971 to 3,124 nucleotides of the M segment (B). Sequences of Rn-DH27 (GQ279393), Z37 (AF187082 and AF190119), ZT10 (AY766368 and DQ159911), ZT71 (AY750171 and EF117248), HuBJ20 (GQ279394), Pf26 (AY006465), zy27 (AF406965), SD201 (GQ279385), Rn-SHY17 (GQ279388), HuBJ15 (GQ279390), HuBJ19 (GQ279389), HuBJ16 (GQ279380), HuBJ7 (GQ279381), HuBJ22 (GQ279379), HuBJ9 (GQ279384), Rn-DC8 (GQ279386), Rn-M11 (GQ279383), Rn-YUE12 (GQ279387), Rn-CP7 (GQ279382), Rn-HD11 (GQ279392), HuBJ3 (GQ279391), BjHD01 (AY627049 and DQ133505), CUI (GQ279395), 93HBX12 (EF192308), SR-11 (M34881 and M34882), 80-39 (NC_005236 and NC_005237), tchoupitoulas (AF329389), IR461 (AF329388 and AF458104), Hb8610 (AF329388), L99 (AF288299 and AF288298), R22 (AF488707), K24-v2 (AF288655 and AF288654), K24-e7 (AF288653 and AF288652), Singapore/06(RN46) (GQ274945 and GQ274943), Singapore/06(RN41) (GQ274944 and GQ274942), CSG11 (AB618113 and AB618131), CSG5 (AB618112 and AB618130), B-1 (X53861), KI-83-262 (D17592), KI-88-15 (D17594), KI-85-1 (D17593), China (EU163437), HB55 (AF035832) and Gou3 (AB027522 and AF145977) were used. Sequences of S and M genome segments of KS74, KS80 and KS90, derived from Rattus norvegicus, correspond to AB697613-AB697615 and AB697616-AB697618, respectively.

where original Rattus rodents appeared and spread to other areas. Therefore, Indonesia is inhabited by many unique rats [1]. Thus, not only SEOV but also various other types of hantaviruses might exist in many unique rodents in Indonesia and spread to Southeast Asian countries. In fact, after the discovery of SERV in Indonesia [15], SERV-like viruses were also discovered in Singapore [9]. In this paper, we failed to detect hantaviruses from $R$. tanezumi captured in Thousand Island district. Because antibody prevalence rate among $R$. tanezumi was lower than $R$. norvegicus and viral genome was not detected from any them, spillover infection of $R$. norvegicus-borne SEOV to $R$. tanezumi is suggested. It was very similar to the situation of SEOV infection in Haiphong port, Vietnum [22]. In addition to the difficulties of virus detection, taxonomic classification of $R$. tanezumi in Asia has also not yet been fixed [1]. Furthermore, genetical comparison between $R$. tanezumi in Serang district and Thosand Island district has not been completed. To understand situation of Rattus-borne hantaviurses in nature, additional informations of hantaviruses and host animals are required 
in future.

Prevalences of hantavirus infection in rodents were higher in populated islands, such as Tidung, Panggang and Untung Jawa Islands. Hantaviruses might have been easily introduced and maintained in these populated islands, because rodents have an abundant food supply from garbage and can reproduce efficiently. Indeed, the prevalence of hantavirus infection in rodents in Tidung and Panggang Islands in 2009 was continuously high as that in 2005 .

Despite the relatively high prevalence in rodents in Tidung and Panggang Islands, antibodies against hantaviruses were not detected from residents of these islands, implying that the risk of hantavirus infection in humans may not be high in those islands. However, it is important to try to avoid direct and indirect contacts with rodents and improve hygiene, because rodents have a number of pathogens.

All of the rodents captured in Thousand Islands were infested with at least one group of ectoparasites (fleas, lice, tick or mites). The only species of flea found in this study was Xenopsylla cheopis, which is known as a vector of plague, and the flea index (average number of fleas per host) was 2.8 for $R$. norvegicus and 0.4 for $R$. tanezumi. It has been reported that a flea index of greater than 1 for $X$. cheopis on rats represents a potentially dangerous situation with respect to increased plague risk for humans [4]. These observations suggest that the potential risk for outbreaks of plague as well as other rodent-borne diseases in the district is high. Continuous investigation in this area is needed to control rodent-borne diseases and improve public health.

We found SEOV-infected rodents in tiny islands, the perimeters of which are as small as several kilometers. The isolated nature and small sizes of these islands are suitable for monitoring the pathogen and reservoirs, evaluating the outcome of countermeasures and studying the ecology of hantaviruses in nature.

ACKNOWLEDGMENTS. This study was supported in part by a grant from the US-Japan co-operative program for Asian countries and The APBN FY 2004 of Indonesian Government. This study was also supported in part by the Program of Founding Research Centers for Emerging and Reemerging Infectious Diseases, Ministry of Education, Culture, Sports, Science and Technology, Japan. This work was also supported in part by a grant from the Global COE program "Establishment of International Collaboration Centers for Zoonosis Control" and by Grants-in-Aid for Research on Emerging and Re-emerging Infectious Diseases from the Ministry of Health, Labour and Welfare including H22-emerging-ippan-006.

\section{REFERENCES}

1. Aplin, K. P., Suzuki, H., Chinen, A. A., Chesser, R. T., Ten Have, J., Donnellan, S. C., Austin, J., Frost, A., Gonzalez, J. P., Herbreteau, V., Catzeflis, F., Soubrier, J., Fang, Y. P., Robins, J., Matisoo-Smith, E., Bastos, A. D., Maryanto, I., Sinaga, M. H., Denys, C., Van Den Bussche, R. A., Conroy, C., Rowe, K. and Cooper, A. 2011. Multiple geographic origins of commensal- ism and complex dispersal history of Black Rats. PLoS One 6: e26357. [Medline] [CrossRef]

2. Blasdell, K., Cosson, J. F., Chaval, Y., Herbreteau, V., Douangboupha, B., Jittapalapong, S., Lundqvist, A., Hugot, J. P., Morand, S. and Buchy, P. 2011. Rodent-borne hantaviruses in Cambodia, Lao PDR, and Thailand. Ecohealth 8: 432-443. [Medline] [CrossRef]

3. Chandy, S., Okumura, M., Yoshimatsu, K., Ulrich, R. G., John, G. T., Abraham, P., Arikawa, J. and Sridharan, G. 2009. Hantavirus species in India: a retrospective study. Indian J. Med. Microbiol. 27: 348-350. [Medline]

4. Gage, K. L. 1999. Plague surveillance. pp. 135-165. In: Plague Manual: Epidemiology, Distribution, Surveillance and Control (WHO/CDS/CSR/EDC/99.2), World Health Organization, Geneva.

5. Gamage, C. D., Yasuda, S. P., Nishio, S., Kularatne, S. A., Weerakoon, K., Rajapakse, J., Nwafor-Okoli, C., Lee, R. B., Obayashi, Y., Yoshimatsu, K., Arikawa, J. and Tamashiro, H. 2011. Serological evidence of Thailand virus-related hantavirus infection among suspected leptospirosis patients in Kandy, Sri Lanka. Jpn. J. Infect. Dis. 64: 72-75. [Medline]

6. Groen, J., Suharti, C., Koraka, P., van Gorp, E. C., Sutaryo, J., Lundkvist, A. and Osterhaus, A. D. 2002. Serological evidence of human hantavirus infections in Indonesia. Infection 30: 326-327. [Medline] [CrossRef]

7. Huong, V. T., Yoshimatsu, K., Luan, V. T., Tuan, L. V., Nhi, L., Arikawa, J. and Nguyen, T. M. N. 2010. Hemorrhagic fever with renal syndrome in Vietnam. Emerg. Infect. Dis. 16: 363-365. [Medline] [CrossRef]

8. Ibrahim, I. N., Sudomo, M., Morita, C., Uemura, S., Muramatsu, Y., Ueno, H. and Kitamura, T. 1996. Seroepidemiological survey of wild rats for Seoul virus in Indonesia. Jpn. J. Med. Sci. Biol. 49: 69-74. [Medline]

9. Johansson, P., Yap, G., Low, H. T., Siew, C. C., Kek, R., Ng, L. C. and Bucht, G. 2010. Molecular characterization of two hantavirus strains from different rattus species in Singapore. Virol. J. 7: 15. [Medline] [CrossRef]

10. Kosasih, H., Ibrahim, I. N., Wicaksana, R., Alisjahbana, B., Hoo, Y., Yo, I. H., Antonjaya, U., Widjaja, S., Winoto, I., Williams, M. and Blair, P. J. 2011. Evidence of human hantavirus infection and zoonotic investigation of hantavirus prevalence in rodents in western Java, Indonesia. Vector Borne Zoonotic Dis. 11: 709-713. [Medline] [CrossRef]

11. Lee, H. W., Calisher, C. and Schmaljohn, C. S. 1999. Manual of Hemorrhagic Fever with Renal Syndrome and Hantavirus Pulmonary Syndrome, WHO Collaborating Center for Virus Reference and Research, Seoul.

12. Luan, V. D., Yoshimatsu, K., Endo, R., Taruishi, M., Huong, V. T., Dat, D. T., Tien, P. C., Shimizu, K., Koma, T., Yasuda, S. P., Nhi, L., Huong, V. T. and Arikawa, J. 2012. Studies on hantavirus infection in small mammals captured in Southern and Central Highland area of Vietnam. J. Vet. Med. Sci. 74: 1155-1162. [Medline] [CrossRef]

13. Okumura, M., Yoshimatsu, K., Kumperasart, S., Nakamura, I., Ogino, M., Taruishi, M., Sungdee, A., Pattamadilok, S., Ibrahim, I. N., Erlina, S., Agui, T., Yanagihara, R. and Arikawa, J. 2007. Development of serological assays for Thottapalayam virus, an insectivore-borne Hantavirus. Clin. Vaccine Immunol. 14: 173-181. [Medline] [CrossRef]

14. Pattamadilok, S., Lee, B. H., Kumperasart, S., Yoshimatsu, K., Okumura, M., Nakamura, I., Araki, K., Khoprasert, Y., Dangsupa, P., Panlar, P., Jandrig, B., Kruger, D. H., Klempa, B., Jakel, T., Schmidt, J., Ulrich, R., Kariwa, H. and Arikawa, J. 2006. 
Geographical distribution of hantaviruses in Thailand and potential human health significance of Thailand virus. Am. J. Trop. Med. Hyg. 75: 994-1002. [Medline]

15. Plyusnina, A., Ibrahim, I. N. and Plyusnin, A. 2009. A newly recognized hantavirus in the Asian house rat (Rattus tanezumi) in Indonesia. J. Gen. Virol. 90: 205-209. [Medline] [CrossRef]

16. Plyusnin, A., Vapalahti, O. and Lundkvist, A. 1996. Hantaviruses: genome structure, expression and evolution. J. Gen. Virol. 77: 2677-2687. [Medline] [CrossRef]

17. Plyusnina, A., Ibrahim, I. N., Winoto, I., Porter, K. R., Gotama, I. B., Lundkvist, A., Vaheri, A. and Plyusnin, A. 2004. Identification of Seoul hantavirus in Rattus norvegicus in Indonesia. Scand. J. Infect. Dis. 36: 356-359. [Medline] [CrossRef]

18. Reynes, J. M., Soares, J. L., Hue, T., Bouloy, M., Sun, S., Kruy, S. L., Flye Sainte Marie, F. and Zeller, H. 2003. Evidence of the presence of Seoul virus in Cambodia. Microbes Infect. 5: 769-773. [Medline] [CrossRef]

19. Schmaljohn, C. and Hjelle, B. 1997. Hantaviruses: a global disease problem. Emerg. Infect. Dis. 3: 95-104. [Medline] [CrossRef]

20. Schmaljon, C. and Hooper, J. W. 2001. Bunyaviridae: the viruses and their replication. pp. 1581-1602. In: Fields Virology, 4th ed. (Knipe, D. M. and Howley, P. eds.), Lippincott, Williams and Wilkins, Philadelphia.
21. Truong, T. T., Yoshimatsu, K., Araki, K., Lee, B. H., Nakamura, I., Endo, R., Shimizu, K., Yasuda, S. P., Koma, T., Taruishi, M., Okumura, M., Truong, U. N. and Arikawa, J. 2009. Molecular epidemiological and serological studies of hantavirus infection in Northern Vietnam. J. Vet. Med. Sci. 71: 1357-1363. [Medline] [CrossRef]

22. Wang, H., Yoshimatsu, K., Ebihara, H., Ogino, M., Araki, K., Kariwa, H., Wang, Z., Luo, Z., Li, D., Hang, C. and Arikawa, J. 2000. Genetic diversity of hantaviruses isolated in china and characterization of novel hantaviruses isolated from Niviventer confucianus and Rattus rattus. Virology 278: 332-345. [Medline] [CrossRef]

23. Yoshimatsu, K., Arikawa, J. and Kariwa, H. 1993. Application of a recombinant baculovirus expressing hantavirus nucleocapsid protein as a diagnostic antigen in IFA test: cross reactivities among 3 serotypes of hantavirus which causes hemorrhagic fever with renal syndrome (HFRS). J. Vet. Med. Sci. 55: 1047-1050. [Medline] [CrossRef]

24. Yoshimatsu, K., Arikawa, J., Yoshida, R., Li, H., Yoo, Y. C., Kariwa, H., Hashimoto, N., Kakinuma, M. and Azuma, I. 1995. Production and application of recombinant hantavirus nucleocapsid protein expressed in silkworm larvae as a diagnostic antigen for laboratory rat. Lab. Anim. Sci. 45: 647-651. 